\title{
Isolation and genotyping of Mycobacterium bovis in suggestive lesions of tuberculosis in cattle slaughtered in the state of Ceará, Brazil ${ }^{1}$
}

\author{
Felipe F. Ferreira ${ }^{2 *}$ (D), Maria L.M. Oliveira ${ }^{2}$, Fernando Alzamora Filho ${ }^{3}$ (D), \\ Bruno R. Santos ${ }^{3}$, Luenny C.S.S.C. Araújo ${ }^{2}$, Evelin S.V. Santos ${ }^{4,5}$ (D), \\ Harrison M. Gomes ${ }^{6}$ and Joselito N. Costa ${ }^{7}$
}

\begin{abstract}
Ferreira F.F., Oliveira M.L.M., Alzamora Filho F., Santos B.R., Araújo L.C.S.S.C., Santos E.S.V., Gomes H.M. \& Costa J.N. 2020. Isolation and genotyping of Mycobacterium bovis in suggestive lesions of tuberculosis in cattle slaughtered in the state of Ceará, Brazil. Pesquisa Veterinária Brasileira 40(11):863-870. Agência de Defesa Agropecuária do Estado do Ceará, Avenida Dr. José Martins Rodrigues 150, Edson Queiroz, Fortaleza, CE 60811-520, Brazil. E-mail: felipefrancelinovet@gmail.com

Bovine tuberculosis (BTB) is a zoonosis caused by the bacterium Mycobacterium bovis, which induces the development of nodular and granulomatous lesions in various animal tissues. The recognition of these suggestive gross lesions during postmortem sanitary inspection in slaughterhouses provides a presumptive diagnosis, which requires the use of complementary tests to confirm the disease. This study aimed to verify the occurrence of BTB in cattle slaughtered in slaughterhouses in the state of Ceará, Brazil, using bacteriological and molecular methods. To this end, suggestive lesions were analyzed on carcasses condemned by the "Serviço de Inspeção Estadual" (SIE). The samples were submitted to microbiological analysis using culture media and specific staining followed by spoligotyping molecular technique for identification and genotyping of the mycobacteria. Occurrence of lesions suggestive of BTB was verified in bovine carcasses $(0.071 \%)$ from different municipalities of the state. These lesions were located mainly in the lung (95.12\%), lymph nodes (58.53\%), and liver (36.58\%). Microbiological culture showed bacterial isolation (17.94\%), with the growth of colonies showing morphological and tannic characteristics belonging to genus Mycobacterium spp. Genetic polymorphism analysis identified $M$. bovis in all isolates, which were discriminated into six spoligotypes (SB0121, SB0295, SB1064, SB0120, SB0870, and SB0852). These profiles have been described in Brazil and several areas of the world, except for profiles SB1064 and SB0852, which were described in the country for the first time. The results show that the association of the diagnostic methods used was the basis for the first study on identification of mycobacteria found in the state, which may provide a database for the epidemiological study of BTB in the state of Ceará.
\end{abstract}

INDEX TERM: Genotyping, Mycobacterium bovis, lesions, tuberculosis, cattle, slaughter, Brazil, sanitary inspection, zoonosis, bovine tuberculosis, spoligotyping.

RESUMO.- [Isolamento e tipificação genética de Mycobacterium bovis em lesões sugestivas de tuberculose em bovinos abatidos no estado do Ceará.] A tuberculose bovina (TB) é uma zoonose causada pelo Mycobacterium bovis, o qual induz ao desenvolvimento de lesões nodulares e granulomatosas

\footnotetext{
${ }^{1}$ Received on June 10, 2020.

Accepted for publication on August 4, 2020

${ }^{2}$ Agência de Defesa Agropecuária do Estado do Ceará (Adagri), Avenida Dr. José Martins Rodrigues 150, Edson Queiroz, Fortaleza, CE 60811-520, Brazil. *Corresponding author: felipefrancelinovet@gmail.com

${ }^{3}$ Universidade Estadual de Santa Cruz (UESC), Campus Soane Nazaré de Andrade, Rod. Jorge Amado Km 16, Salobrinho, Ilhéus, BA 45662-900, Brazil.
}

em vários tecidos do animal. 0 reconhecimento dessas lesões macroscópicas sugestivas durante a inspeção sanitária post mortem em matadouros fornece um diagnóstico presuntivo, sendo necessário a utilização de testes complementares para confirmação da doença. 0 objetivo deste trabalho foi verificar

\footnotetext{
${ }^{4}$ Universidade Federal da Bahia (UFBA), Rua Augusto Viana s/n, Canela, Salvador, BA 40110-909, Brazil.

${ }^{5}$ Instituto Federal de Educação, Ciência e Tecnologia Baiano (IFBaiano), Av. Júlio José Rodrigues Km 2, Clerolandia, Itapetinga, BA 45700-000, Brazil.

${ }^{6}$ Fundação Oswaldo Cruz (Fiocruz), Av. Brasil 4365, Manguinhos, Rio de Janeiro, RJ 21040-900, Brazil.

Universidade Federal do Recôncavo da Bahia (UFRB), Rua Rui Barbosa 710, Centro, Cruz das Almas, BA 44380-000, Brazil.
} 
a ocorrência da TB em animais abatidos em matadourosfrigoríficos no estado do Ceará através da utilização de métodos bacteriológicos e moleculares. Para tanto, foram analisadas lesões sugestivas de TB em carcaças condenadas pelo Serviço de Inspeção Estadual (SIE). As amostras foram submetidas à análise microbiológica, utilizando meios de cultivo e de coloração específicos, seguida pela técnica molecular spoligotyping para identificação e tipificação genética da micobactéria. Verificou-se a ocorrência de lesões sugestivas de TB em carcaças bovinas $(0,071 \%)$ oriundas de diferentes municípios do estado do Ceará. Essas lesões estavam localizadas principalmente no pulmão $(95,12 \%)$, linfonodos (58,53\%) e fígado (36,58\%). 0 cultivo microbiológico obteve isolamento bacteriano $(17,94 \%)$, com o crescimento de colônias apresentando características morfológicas e tintoriais pertencentes ao gênero Mycobacterium spp. A análise do polimorfismo genético identificou a presença de $M$. bovis em todos os isolados, que foram discriminados em seis espoligotipos (SB0121, SB0295, SB1064, SB0120, SB0870 e SB0852), descritos no Brasil e em diversas áreas do mundo, exceto os perfis SB1064 e SB0852 que foram descritos pela primeira vez no país. Os resultados obtidos demonstram que a associação dos métodos diagnósticos utilizados foram a base do primeiro estudo de identificação das micobactérias encontradas no estado do Ceará, o que pode contribuir para a criação de um banco de dados para o estudo epidemiológico da TB no estado.

TERMOS DE INDEXAC̄̃̃: Tipificação genética, Mycobacterium bovis, lesões, tuberculose, bovinos, abatedouro, Brazil, inspeção sanitária, zoonose, tuberculose bovina, spoligotyping.

\section{INTRODUCTION}

Bovine tuberculosis (BTB) is an infectious and contagious disease of progressive character and chronic evolution caused mainly by the bacterium Mycobacterium bovis. It is characterized by development of nodular and granulomatous lesions in different organs, mainly in the lung, since the main form of transmission occurs through inhalation of aerosols (Paes \& Franco 2016). BT is of great importance in public and animal health due to its zoonotic potential, determining a situation of high morbidity and mortality in humans (PérezLago et al. 2014). In addition, it causes marked economic losses in cattle herds as a result of animal death, reduced milk production and weight gain, reproductive changes, animal disposal, and carcass condemnation (Pacheco et al. 2009, Paes \& Franco 2016).

Brazil has the largest commercial cattle herd globally, with approximately 214.89 million head (IBGE 2017). Consequently, animal products destined for the domestic and foreign markets must present high quality and low health risk.

onducting epidemiological surveys in slaughterhouses is an indicator of BT prevalence in cattle destined for slaughter and, therefore, of the probability of human exposure through infected meat consumption (Biffa et al. 2010). In the state of Ceará, surveillance for BT in slaughterhouses has not been reported. Only one epidemiological survey on BT has been identified in the state of Ceará. This survey was carried out in rural settlements in the municipality of Quixerambim, in which 248 cattle were submitted to tuberculization and no positive animals were identified. However, it cannot be said that there is no tuberculosis in cattle in the surveyed region, as other factors may have contributed to test negativity. These factors include the voluntary adherence of the participating owners and the drought that spread in the region, which may have contributed to the death of debilitated and sick animals, limiting the spread of the disease (Nascimento 2014).

It is known that results obtained from surveillance in slaughterhouses can indicate BT health status in the herd. However, due to the similarity between the disease's lesions and other nodular and granulomatous inflammatory processes, it is often impossible to identify all sick animals (Roxo 1997, Mendes et al. 2013). In general, recognition of gross lesions associated with BT during routine health inspection in slaughterhouses has been the only measure used to diagnose the disease, which may incur errors in its detection, especially in paucibacillary lesions. It is recommended that complementary diagnostic tests be used in these lesions to minimize these misunderstandings (Furlanetto et al. 2012).

Microbiological culture of the etiologic agent is the certified method for direct diagnosis. However, it presents low sensitivity and prolonged time between primary isolation and final identification of the species (Corner 1994). In contrast, an alternative that enables rapid identification of mycobacteria is the application molecular techniques, which can distinguish between different strains, allowing increased sensitivity and specificity and a decrease in the number of diagnoses of this infection (Ramos et al. 2015). Some studies have demonstrated the possibility of using polymerase chain reaction (PCR) and spoligotyping techniques to detect and type $M$. bovis in fragments of lesions collected in slaughterhouses (Rodriguez et al. 2004, Costa et al. 2012, Parreiras et al. 2012, Alzamora Filho et al. 2014b).

This study aimed to analyze the occurrence of BTB in the state of Ceará through the isolation, identification, and genetic characterization of $M$. bovis from gross lesions suggestive of tuberculosis in cattle slaughtered in slaughterhouses under the "Serviço de Inspeção Estadual".

\section{MATERIALS AND METHODS}

Between August 2017 and September 2018, slaughter and postmortem inspection of cattle were monitored by the "Serviço de Inspeção Estadual" (SIE) of the state of Ceará in three slaughterhouses located in the municipalities of Iguatu and Juazeiro do Norte and of Maracanaú in the metropolitan region of Fortaleza, south and center-south of the state. Data on the animals' origin were obtained from the "Guia de Trânsito Animal" (GTA). An additional assessment of cattle traceability was carried out by analyzing the health records of producers and rural properties obtained from the "Agência de Defesa Agropecuária do Estado do Ceará”, Ceará state (ADAGRI 2019).

According to methods recommended by Ministério da Agricultura, Pecuária e Abastecimento (MAPA) through the "Regulamento da Inspeção Industrial e Sanitária de Produtos de Origem Animal" RIISPOA (Brasil 2017), samples of lesions suggestive of BTB were collected by veterinary medical inspectors during routine health inspection of beef. Data on the characteristics and location of these lesions were recorded on slaughter follow-up forms.

For bacteriological exams, the collected samples were placed in sterile universal type collectors, identified, and stored at $-20^{\circ} \mathrm{C}$ or in saturated sodium borate decahydrate solution (Na2B407 • $10 \mathrm{H} 20,140 \mathrm{~g} / \mathrm{L}$ ), which preserves mycobacteria for up to 60 days at room temperature (Richards \& Wright 1983). Subsequently, 
the samples were sent to the "Laboratório de Micobacterioses" of the "Universidade Estadual de Santa Cruz" (LAMVET-UESC), Ihéus, state of Bahia, for processing and bacteriological analysis. Initially, the tissue fragments were decontaminated using $1.5 \%$ 1-hexadecylpyridinium chloride (HPC) for $30 \mathrm{~min}$. Then they were inoculated in Stonebrink-Leslie and Lowenstein-Jensen culture media and incubated at $37^{\circ} \mathrm{C}$ for up to 90 days. After the cultivation period, the isolated colonies were stained using the Ziehl-Neelsen (ZN) method for staining characterization of alcohol-acid resistant bacilli (AARB) (Rodriguez 2005, Brasil 2008).

From the isolates characterized as AARB, a bacterial suspension was performed in $200 \mu \mathrm{L}$ of Tris-EDTA (TE) buffer solution $(10 \mathrm{mM}$ Tris-HCl; 1mM EDTA; pH 8.0) to inactivate the bacterium, and later DNA extraction was obtained by thermal lysis through incubation at $90^{\circ} \mathrm{C}$ for $30 \mathrm{~min}$, followed by centrifugation (Shi et al. 2018). The resulting DNA was taken to the "Laboratório de Biologia Molecular" applied to mycobacteria of the "Fundação Oswaldo Cruz" (FIOCRUZ - Rio de Janeiro), where molecular analyses were carried out.

Identification of Mycobacterium bovis was confirmed through molecular typing, and analysis of genetic polymorphism was performed using the Spoligotyping technique, as described by Kamerbeek et al. (1997). Direct region amplification was performed in a final volume of $50 \mu \mathrm{L}$ with $0.2 \mathrm{mM}$ containing dNTP $(10 \mathrm{mM}$ Tris- $\mathrm{HCl}, \mathrm{pH}$ 8.0; $50 \mathrm{mM} \mathrm{KCl}$ ), $1.5 \mathrm{mM} \mathrm{MgCl} 2,20$ pmol of primers for each primer (biotinylated DRa and DRb), and $1 \mathrm{U}$ of Taq DNA polymerase and 10ng of DNA. The polymerase chain reaction (PCR) consisted of an initial denaturation at $96{ }^{\circ} \mathrm{C}$ for 3 min., 20 cycles of amplification at $96^{\circ} \mathrm{C}$ for $1 \mathrm{~min}$., $55^{\circ} \mathrm{C}$ for $1 \mathrm{~min}$, and $72^{\circ} \mathrm{C}$ for $30 \mathrm{~s}$, followed by a final extension at $72^{\circ} \mathrm{C}$ for $5 \mathrm{~min}$. M. bovis BCG DNA was used as a positive control, whereas ultrapure water was the negative control. The PCR products were membrane hybridized containing 43 oligonucleotides of known spacer sequences. After incubation with streptavidinperoxidase, the spacers were detected by chemiluminescence. The polymorphic patterns obtained in hybridization were compared with an international database for $M$. bovis available in the literature (Kremer et al. 1999, Van Embden et al. 2000, Haddad et al. 2001). The nomenclature adopted for the spoligotypes obtained was the same as that available in the Sitvit Web database (Machado et al. 2014) and on the website ${ }^{8}$.

\section{RESULTS}

In the study period, 57,347 cattle were evaluated during the inspection routine for health on ante-mortem examination, but did not undergo tuberculosis screening tests. Of these, 41 animals $(0.071 \%)$ presented lesions suggestive of tuberculosis at postmortem inspection and had their carcasses condemned in whole or in part by the SIE inspectors. Considering the gross findings of the official service, the percentage of condemnation (slaughtered cattle condemned because of lesions suggestive of BTB) was $0.32 \%$ (24/7374), 0.06\% (15/25694), and 0.01\% $(2 / 24279)$ in the three slaughterhouses under the SIE of the state of Ceará (Table 1). The analysis of the mandatory animal health documents (GTA) showed that the sampled cattle belonged to herds from 13 municipalities located in different regions of the state of Ceará: Fortaleza, Caucaia, Cascavel, Ocara, Tauá, Saboeiro, Quixelô, Jucás, Iguatu, Icó, Cedro, Cariús, and Crato, with a positive diagnosis of BTB

\footnotetext{
8 Available at $<$ www.mbovis.org $>$
}

confirmed in three of these municipalities (Jucás, Iguatu, and Quixelô), as shown in Figure 1.

The condemned animals presented firm, nodular lesions, focal to multifocal, with a purulent or caseous aspect, presence of fibrous capsule, in some cases showing areas of calcification in the center of the lesion, evidenced by knife creaking at cut. These lesions, present in one or more tissues of the same animal, were located mainly in the lungs (95.12\%) and lymph nodes (58.53\%), as well as on the head, neck, thoracic lymph nodes, and liver (36.58\%). In addition, two cattle were identified with suggestive nodules in the spleen and kidney, each associated with liver and lung injuries (Table 2). At the gross examination

Table 1. Occurrence of cattle with lesions suggestive of bovine tuberculosis (BTB) in slaughterhouses under the "Serviço de Inspeção Estadual" (SIE) in the state of Ceará, Brazil

\begin{tabular}{|c|c|c|c|}
\hline \multirow{2}{*}{$\begin{array}{l}\text { Slaughterhouses } \\
\text { SIE }\end{array}$} & \multicolumn{2}{|c|}{ Number of cattle } & \multirow{2}{*}{$\begin{array}{c}\text { Condemnation } \\
(\%)\end{array}$} \\
\hline & Slaughtered & $\begin{array}{c}\text { Suggestive BTB } \\
\text { lesions }\end{array}$ & \\
\hline A & 24,279 & 2 & 0.008 \\
\hline B & 7374 & 24 & 0.325 \\
\hline $\mathrm{C}$ & 25,694 & 15 & 0.058 \\
\hline Total & 57,347 & 41 & 0.071 \\
\hline
\end{tabular}

Table 2. Gross lesions suggestive of bovine tuberculosis (BTB) in animals condemned by the "Serviço de Inspeção Estadual" (SIE) in the state of Ceará, Brazil

\begin{tabular}{lcc}
\hline \multicolumn{1}{c}{ Lesion location } & Number of lesions* & $\begin{array}{c}\text { Occurrence of lesions in } \\
\text { condemned animals (\%) }\end{array}$ \\
\hline Lung & 39 & 95.12 \\
Lymph nodes & 24 & 58.53 \\
Liver & 15 & 36.58 \\
Spleen & 01 & 2.43 \\
Kidney & 01 & 2.43
\end{tabular}

*N = 41 bovines; in total, 80 fragments of lesions located in different organs were collected, and one or more lesions suggestive of BTB were collected from the same animal (sample).

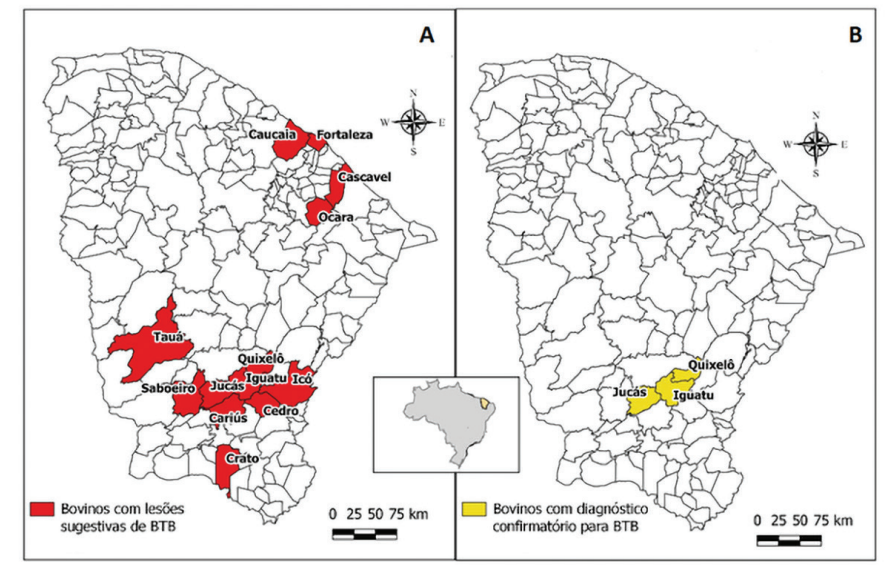

Fig.1. Map of the state of Ceará, Brazil, highlighting (A) origin municipalities of the cattle with lesions suggestive of bovine tuberculosis (BTB) condemned by the Serviço de Inspeção Estadual (SIE), (B) municipalities where the bovines came from, whose suggestive lesions had a confirmatory diagnosis for Mycobacterium bovis. 
of the lung lesions, the initially noticeable nodules on the lobes surface were deepened by cutting the parenchyma. Bovine carcasses that showed lesions not suggestive of BTB, considered only as common or nonspecific lymphadenitis by the SIE evaluation, did not have their samples collected.

Of the samples of presumptive BTB lesions collected by the official service, two were discarded due to tissue autolysis, and 39 were processed and cultured. The bacteriological analysis revealed bacterial isolation in $17.94 \%$ (7/39) of the samples, with growth of small, rounded, cream-yellowish colonies with irregular edges and granular surface in the Stonebrink-Leslie culture medium, with average observed time for the appearance of colonies of 28 days- minimum of 16 days and maximum of 32 days. Of the seven positive samples in the Stonebrink-Leslie medium, growth of colonies was observed in three samples in the Lowenstein-Jensen culture medium, with an average time observed for the appearance of colonies of 45 days (minimum 32 days and maximum 64 days). All smears from the 10 isolated colonies presented alcohol-acid resistant bacilli $\left(\mathrm{AARB}^{+}\right)$when subjected to Ziehl-Neelsen (ZN) staining.

Considering the stratification by sex and age group of cattle with positive bacteriological diagnosis for Mycobacterium spp., it was found that $85.71 \%(6 / 7)$ of the animals were female, and only $14.29 \%(1 / 7)$ were male. The age group most affected was over 36 months, with $83.33 \%$ (5/6) of positive females having this age. Of the positive animals, only one young female (16.67\%), aged 13-24 months, was affected by the disease. The municipality of Iguatu stood out as the most affected by BTB, representing the origin of $71.42 \%(5 / 7)$ of the positive cattle diagnosed in the study, and the positive animals were all from different herds and properties (Table 3 ).
In the genetic material of the isolates submitted to the spoligotyping technique, six spoligotypes were identified as Mycobacterium bovis. The studied profiles showed deletions in spacers $3,9,16$, and 39-43, characterizing the pathogen. Of the seven samples, three showed two different spoligotypes each, which justifies seven positive animals and 10 isolates. Six spoligotypes previously identified in the databases were observed in the 10 AARB isolates. Three of them formed clusters of genotypes and three had a single profile. Three AARB isolates had spoligotype profile SB0121, two presented SB0295, two showed SB1064, and the single profiles SB0120, SB0852, and SB0870 were found in one isolate (Table 4).

\section{DISCUSSION}

This study found that, according to the SIE, based on the occurrence of gross lesions suggestive of BTB $(0.071 \%)$, this disease is present in the cattle herd of the state of Ceará. Condemnation of cattle carcasses with suspicion of BTB were previously reported by Baptista et al. (2004), who found a prevalence of $0.07 \%$ of suggestive lesions in animals slaughtered in Minas Gerais. There is a wide variation in BTB prevalence from postmortem inspection of cattle in Brazil (0.17 to $5.16 \%$ ). This difference may be related to the degree of regional development, especially concerning sanitary measures in the herds (Araújo 2004).

In this study, the carcass condemnation rate (CCR) per establishment ranged from 0.01 to $0.32 \%$. These data are probably related to the slaughtering particularities in each establishment, such as type of exploitation, density, and health practices. In the slaughterhouse with the lowest CCR (SIE A), in addition to having a higher slaughtering volume, most of the animals were originated from extensively reared beef herds, a category in which BTB presents sporadic occurrence

Table 3. Origin and stratification by sex and age group of cattle with confirmatory diagnosis for bovine tuberculosis (BTB) in the state of Ceará, Brazil

\begin{tabular}{|c|c|c|c|c|c|c|c|}
\hline \multirow{2}{*}{ Animal } & \multicolumn{2}{|c|}{ Sex } & \multicolumn{4}{|c|}{ Age group (in months) } & \multirow{2}{*}{ Municipality of origin } \\
\hline & Female & Male & 0 to 12 & 13 to 24 & 25 to 36 & $>36$ & \\
\hline Bovine 1 & 1 & - & - & - & - & 1 & Iguatu \\
\hline Bovine 2 & 1 & - & - & - & - & 1 & Iguatu \\
\hline Bovine 3 & 1 & - & - & - & - & 1 & Iguatu \\
\hline Bovine 4 & - & 1 & - & - & 1 & - & Jucás \\
\hline Bovine 5 & 1 & - & - & - & - & 1 & Quixelô \\
\hline Bovine 6 & 1 & - & - & 1 & - & - & Iguatu \\
\hline Bovine 7 & 1 & - & - & - & - & 1 & Iguatu \\
\hline TOTAL & 6 & 1 & - & 1 & 1 & 5 & - \\
\hline
\end{tabular}

Table 4. Spoligotyping of Mycobacterium bovis strains isolated from cattle slaughtered in slaughterhouses under the "Serviço de Inspeção Estadual" (SIE) in the state of Ceará, Brazil

\begin{tabular}{|c|c|c|c|}
\hline Spoligotype pattern* & Spoligotype profile** & Isolates $(n)$ & Municipality of origin \\
\hline SB0121 & 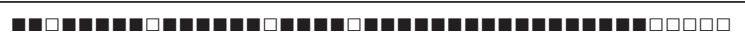 & 3 & Iguatu \\
\hline SB0295 & 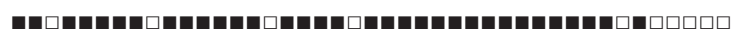 & 2 & Quixelô \\
\hline SB1064 & 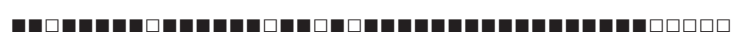 & 2 & Iguatu, Jucás \\
\hline SB0120 & 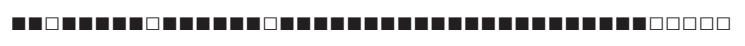 & 1 & Iguatu \\
\hline SB0852 & 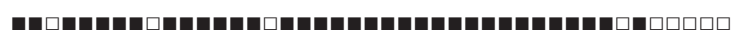 & 1 & Iguatu \\
\hline SB0870 & 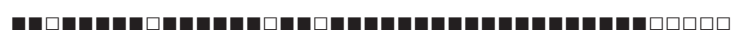 & 1 & Iguatu \\
\hline
\end{tabular}

* International name given by Mbovis.org. and SitVitWeb, ${ }^{* *}$ Black and white boxes indicate the presence and absence, respectively, of the specific spacer in position 1-43 in the direct repeat (DR) locus. 
(Rodriguez 2005). In contrast, in the establishment with the highest CCR (SIE - B), this value is possibly related to the increased slaughter of animals discarded from dairy or mixed herds concentrated in the region, cases in which the probability of BTB occurrence increases (Costa et al. 2012). Moreover, detection of lesions suggestive of BTB depends on the time available to scrutinize the carcass. A short time may be insufficient to identify discreet lesions, and this identification may also be hindered by lack of inspection experience. In this way, the slaughter inspection accuracy probably varies between regions and slaughterhouses (Perrez et al. 2002, Alzamora Filho et al. 2014a).

In the present study, it was observed that the organ most affected by lesions suggestive of BTB was the lung, followed by the lymph node chain, and the liver, which is in agreement with results obtained in other studies (Alzamora Filho et al. 2014a, Silva et al. 2014). The more significant occurrence of lung lesions may be directly related to inhalation of contaminated aerosols, which are eliminated through the cough or nasal discharge of infected animals, occurring mainly in dairy herds as a result of high population density and confinement (Paes \& Franco 2016). The predominant lesions in this study are in line with the description of focal, multifocal, or diffuse nodular lesions in affected organs (Costa et al. 2013), with a high occurrence of caseous and calcified lung injuries (Silva et al. 2014). In the generalized form of BTB, dissemination of the bacillus reaches several organs such as the spleen, udders, and kidneys (Oliveira et al. 2012), corroborating the gross findings of detected renal and splenic lesions.

Regarding the bacteriological analysis, considering the characteristics of the colonies described by Corner (1994), colonies compatible with Mycobacterium bovis were isolated in only seven samples, which reflected a sensitivity of $17.94 \%$ for this method. Due to the characteristics of the lesions obtained in slaughterhouses, many isolations of the pathogen were expected. As verified by Fráguas et al. (2008), in the present study, the low sensitivity of the bacteriological culture may be associated with the decontamination techniques used in the processing of samples. These techniques may have contributed to death of the bacilli and the consequent low index of mycobacterial isolation, especially in paucibacillary samples. Low rates of mycobacterial isolation have been reported in previous studies addressing lesions suggestive of BTB (Pinto et al. 2002, Araújo et al. 2005). It can also be explained by the occurrence of nodular and granulomatous inflammatory processes determined by other etiologies, with specific characteristics, and undifferentiated gross features of BTB, such as lymphosarcoma, actinomycosis, actinobacillosis, and nocardiosis (Roxo 1997, Mendes et al. 2013, Paes \& Franco 2016). The absence or deficiency of viable pathogens in suggestive gross lesions may also be associated with the difficulty of the pathogen to multiply in culture, because the lesions present a bacillary concentration below 10,000 $\mathrm{CFU} / \mathrm{mL}$ (Zanini et al. 2001), and the death of mycobacteria after promoting the lesion by defending the organism from the chronic nature of the disease (Pinto et al. 2002, Fráguas et al. 2008). A reduced number of $M$. bovis isolates have also been observed in studies that bacteriologically evaluated both lesions suggestive of BTB and nonspecific lymphadenitis during postmortem examination (Furlanetto et al. 2012, Alzamora Filho et al. 2014a). Considered the gold standard for BTB diagnosis, higher isolation rates are expected in bacteriological culture, with mycobacterial growth rates that can vary from 60.0 (Nassar et al. 2007) to $68.75 \%$ (Silva et al. 2018) of the suggestive lesions. In contrast, despite the low frequency of positive samples verified in the present study, ZN staining revealed $\mathrm{AARB}^{+}$in $100 \%$ of the isolates, confirming the high identification specificity of the mycobacterial method (Corner 1994).

In Brazil, BTB is endemic and affects many dairy properties, since animals are subjected to confinement and high metabolic demand (Brasil 2006). The occurrence of lesions suggestive of BTB had a confirmatory diagnosis for M. bovis in municipalities in the center-south region of Ceará (Fig.1B), a critical dairy basin in the state, with emphasis on the municipality of Iguatu, which is among the 10 municipalities with highest production (IPECE 2018). Among the positive cattle, females aged $>36$ months were the most affected, suggesting that they were culling cows with advanced age for reproduction, probably from dairy or mixed herds located in the affected region. Similar to our results, Grisi Filho et al. (2011), when evaluating animals condemned for BTB according to the isolation of $M$. bovis in the state of São Paulo, reported greater positivity in females (58.89\%). Other studies conducted with female bovines slaughtered at old age, which demonstrated a high occurrence of lesions suggestive of BTB followed by significant positivity rates in bacterial isolation, have also been found in the literature (Damina et al. 2011, Okeke et al. 2014). Those authors suggested that the findings may be related to the chronic character of the disease and the increased exposure of the animals to mycobacteria over time, considering that females have a longer productive life.

In association with classic bacteriological isolation, the use of complementary molecular methods to identify mycobacteria is more sensitive and efficient for a definitive diagnosis of BTB. Spoligotyping is a molecular technique that allows simultaneous detection and typification of the $M$. tuberculosis complex (Kamerbeek et al. 1997). It is referred as the technique of choice for comparing the strain with few copies of IS 6110. Another advantage is the differentiation between M. bovis and M. tuberculosis due to the absence and presence, respectively, of spacers 39 to 43 (Rodriguez et al. 2004). Research on spoligotypes was a vital tool to identify and typify the genotypes of M. bovis present in cattle herds in the state of Ceará. In the present study, six spoligotypes were identified: SB0121, SB0295, SB1064, SB0120, SB0852, and SB0870 with deletions in spacers $3,9,16$, and 39-43, which is characteristic of M. bovis strains (Kamerbeek et al. 1997, Haddad et al. 2004).

Spoligotype SB0121 was the most frequent in the present study (30\%), with a cluster in three isolates registered in the municipality of Iguatu. This predominant genetic profile is in line with the results obtained in other studies in Brazil (Parreira et al. 2012, Rocha et al. 2013, Alzamora Filho et al. 2014b, Ramos et al. 2014, Cazola et al. 2015, Carvalho et al. 2016). In addition to being described as the most frequent spoligotype in Brazil, Mexico (Zumárraga et al. 2013), and Portugal (Ghavidel et al. 2018), it has also been reported in countries such as Argentina, Belgium, Germany, Spain, France, United Kingdom, Italy, Sweden, Tunisia, Uruguay, the United States, and South Africa, as verified in the Sitvit Web database (Machado et al. 2014). 
Spoligotypes SB0295 and SB1064 formed the other two clusters, with two isolates each. SB0295 had a prevalence of 24\% (Zumárraga et al. 2013), and has been described in the states of Mato Grosso, Goiás (Carvalho et al. 2016) Paraíba, Federal District, Minas Gerais, Mato Grosso do Sul and Santa Catarina (Parreiras et al. 2012), São Paulo (Rocha et al. 2013), and Bahia (Alzamora Filho et al. 2014b). This spoligotype has also been reported in Argentina, Belgium, Costa Rica, Spain, Portugal, France, Mexico, and the United States (Sitvit Web). In contrast, spoligotype SB1064 has had its pattern isolated in Portugal (Matos et al. 2010) and Mexico (Sitvit Web).

The profiles SB0120, SB0870, and SB0852 were isolated, each in different samples from the municipality of Iguatu. Spoligotype SB0120 was the most common circulating type on several continents (Ghavidel et al. 2018). In Brazil, it was identified in the states of Paraíba and the Federal District (Parreiras et al. 2012), Bahia (Costa et al. 2012), and São Paulo (Rocha et al. 2013), having importance in other regions of the world. This spoligotype is widespread in several European countries, being mostly described in France with a prevalence of $26 \%$ of the isolates (Haddad et al. 2001). However, it has also been found in Africa and Asia (Sitvit Web). In addition, cases of human tuberculosis caused by M. bovis (spoligotype SB0120) have been reported in the United Kingdom (Gibson et al. 2004), indicating the zoonotic potential of this profile. Spoligotype SB0870, in turn, was reported in a single isolate identified in a sample obtained in the state of São Paulo (Rocha 2013), as well as in some European countries such as Germany, Denmark, and France (Sitvit Web). Spoligotype SB0852 has been reported only in France and the United States (Sitvit Web).

With the molecular discrimination of spoligotypes SB1064 and SB0852, the present study seems to have generated unprecedented results in identifying the polymorphism of genetically typified $M$. bovis isolates in Brazil. This study seems to be the first report of these spoligotype profiles in the country.

The identification of $M$. bovis through bacteriological and molecular methods confirmed the existence of BTB focus properties in the state of Ceará. The tracking of the bovines' origin with confirmatory diagnosis, associated with the evaluation of the transport history of the focus properties, allowed us to identify that the animals of these herds were entered or discharged from properties from 17 different municipalities in the state of Ceará. Bovines with lesions suggestive of BTB originating from six of these municipalities were identified (Fig.1A).

The focus properties showed several cattle, between 52 and 457 animals, with characteristics of mixed or dairy herds. In general, these properties acquired cattle from other rural properties through intra and/or inter-municipal transport, and were characterized by intense movement of animals due to the accentuated inter-municipal cattle trade. In this internal traffic, it is not mandatory to carry out screening exams for GTA issuance. In addition, there was interstate transport of cattle, including the egress of animals to the states of Paraíba and Bahia, and admission from the state of São Paulo - this official transport with exams and GTA issuance. However, there may be unrecorded irregular transport of animals without compliance with sanitary requirements. Previous studies pointed out BTB prevalence or occurrence with a confirmatory diagnosis of $M$. bovis in these states (Rocha et al. 2013, Alzamora Filho et al. 2014a, Ramos et al. 2018). This suggests a possible route for the movement of infected animals between the state of Ceará and these geographic regions, especially with the states of Bahia (Costa et al. 2012, Alzamora Filho et al. 2014a) and São Paulo (Rocha et al. 2013), where the presence of M. bovis strains similar to those identified in this work were previously identified (SB0120, SB 0121, and SB0295).

The transit of cattle with BTB between properties, regions, or countries represents a potentially critical factor for the transmission of this disease (Skuce et al. 2012), which can be confirmed by the genetic diversity of $M$. bovis isolates from bovine carcasses in the state of Ceará. The risk factors frequently identified and described for the disease include free movement of possibly infected animals, occurrence of the disease on the property and in neighboring areas, number of animals, type of exploration, and use of the intensive system, in which herds are kept together for long periods, and entry of animals from herds with a history of BTB (Skuce et al. 2012, Bahiense et al. 2016, Barbieri et al. 2016, Belchior et al. 2016, Dias et al. 2016). Additionally, the history of cattle transported to local livestock events, such as livestock shows and events (vaquejadas), was also verified in focus properties of the present study, which are characterized as important areas of risk for BTB due to the agglomeration of animals of different origins (Brasil 2006).

\section{CONCLUSIONS}

The association of post mortem BTB diagnosis techniques with molecular genotyping techniques were the basis of the first study to identify mycobacteria in the state of Ceará, and this work was the starting point for the creation of a database of great relevance to the epidemiological study of this disease in the state.

In addition, among the genetically typified Mycobacterium bovis isolates, two spoligotypes that had not yet been reported in Brazil were identified (SB1064 and SB0852). Therefore, this study is the first report on these profiles in the country.

Conflict of interest statement.- The authors declare having no conflict of interest concerning the publication of this article.

\section{REFERENCES}

ADAGRI 2019. Novo Sistema de Defesa Agropecuária - Novo SIDAGRO. Agência de Defesa Agropecuária do Estado do Ceará, Fortaleza.

Alzamora Filho F., Reis V.M., Fehlberg I., Alcântara A.C., Cavalcante M.P., Rocha V.C.F. \& Costa J.N. 2014a. Identificação de Mycobacterium bovis em carcaças de bovinos abatidos no estado da Bahia, Brasil, por métodos bacteriológico e molecular. Arq. Bras. Med. Vet. Zootec. 66(5):1585-1591. <https://dx.doi.org/10.1590/1678-6640>

Alzamora Filho F., Vasconcellos S.E.G., Gomes H.M., Cavalcante M.P., Suffys P.N. \& Costa J.N. 2014b. Múltiplas estirpes de isolados de Mycobacterium bovis identificados por tipagem molecular em bovinos abatidos em matadourosfrigoríficos. Pesq. Vet. Bras. 34(2):103-108. <https://dx.doi.org/10.1590/ S0100-736X2014000200001>

Araújo C.P. 2004. Isolamento de Mycobacterium bovis em cultura e sua identificação pela reação de polimerase em cadeia. Master's Thesis, Universidade Federal de Mato Grosso do Sul, Campo Grande. 52p.

Araújo C.P., Leite C.Q.F., Prince K.A., Jorge K.S.G. \& Osório A.L.A.R. 2005. Mycobacterium bovis identification by a molecular method from post- 
mortem inspected cattle obtained in abattoirs of Mato Grosso do Sul, Brazil. Mem. Inst. Oswaldo Cruz 100(7):749-752. <https://dx.doi.org/10.1590/ S0074-02762005000700013>

Bahiens L., Bavia M.E., Amaku M., Dias R.A., Grisi-Filho J.H.H., Ferreira F., Telles E.O., Gonçalves V.S.P., Heinemann M.B. \& Ferreira Neto J.S. 2016. Prevalence and risk factors for bovine tuberculosis in the State of Bahia, Brazil. Semina, Ciênc. Agrárias 37(5supl.2):3549-3560. <https://dx.doi. org/10.5433/1679-0359.2016v37n5Supl2p3549>

Baptista F., Moreira E.C., Santos W.L.M. \& Naveda L.A.B. 2004. Prevalência da tuberculose em bovinos abatidos em Minas Gerais. Arq. Bras. Med. Vet. Zootec. 56(5):577-580.<https://dx.doi.org/10.1590/S0102-09352004000500002>

Barbieri J.M., Oliveira L.F., Dorneles E.M.S., Mota A.L.A.A., Gonçalves V.S.P., Maluf P.P., Ferreira Neto J.S., Ferreira F., Dias R.A., Telles E.O., Grisi Filho J.H.H., Heinemann M.B., Amaku M. \& Lage A.P. 2016. Epidemiological status of bovine tuberculosis in the state of Minas Gerais, Brazil. Semina, Ciênc. Agrárias 37(5supl.2):3531-3548.

Belchior A.P.C., Lopes L.B., Gonçalves V.S.P. \& Leite R.C. 2016. Prevalence and risk factors for bovine tuberculosis in Minas Gerais State, Brazil. Trop. Anim. Health Prod. 48(2):373-378. <https://dx.doi.org/10.1007/ s11250-015-0961-x><PMid:26584941>

Biffa D., Bogale A. \& Skjerve E. 2010. Diagnostic efficiency of abattoir meat inspection service in Ethiopia to detect carcasses infected with Mycobacterium bovis: Implications for public health. BMC Public Health 10:462. <https:// dx.doi.org/10.1186/1471-2458-10-462><PMid:20691081>

Brasil 2006. Manual Técnico do Programa Nacional de Controle e Erradicação da Brucelose e Tuberculose Animal - PNCEBT. Ministério da Agricultura, Pecuária e Abastecimento, Brasília, DF. 188p.

Brasil 2008. Manual Nacional de Vigilância Laboratorial da Tuberculose e outras Micobactérias. Ministério da Saúde, Brasília. 436p.

Brasil 2017. Regulamenta a Lei oㅡ 1.283, de 18 de dezembro de 1950, e a Lei no 7.889, de 23 de novembro de 1989, que dispõem sobre a inspeção industrial e sanitária de produtos de origem animal. Decreto $n^{\circ} 9.013$, de 29 de Março de 2017, Ministério da Agricultura, Pecuária e Abastecimento, Brasília, DF. Available at <http://pesquisa.in.gov.br/imprensa/jsp/visualiza/ index.jsp?data $=30 / 03 / 2017$ \&jornal $=1$ \&pagina $=3$ \&totalArquivos $=240>$ Accessed on Mar. 5, 2019.

Carvalho R.C.T., Vasconcellos S.E.G., Issa M.A., Soares Filho P.M., Mota P.M.P.C., Araújo F.R., Carvalho A.C.S., Gomes H.M., Suffys P.N., Figueiredo E.E.C., Margaret V. \& Paschoalin F. 2016. Molecular Typing of Mycobacterium bovis from cattle reared in Midwest Brazil. Plos One 11(9):e0162459.<https:// dx.doi.org/10.1371/journal.pone.0162459>

Cazola D.O., Jorge K.S.G., Zumárraga M.J., Souza-Filho A.F., Araújo F.R. \& Osório A.L.A.R. 2015. Identificação e genotipagem de Mycobacterium bovis em bovinos positivos no teste intradérmico para tuberculose em Mato Grosso do Sul. Pesq. Vet. Bras. 35(2):141-147. <https://dx.doi.org/10.1590/ S0100-736X2015000200008>

Corner L.A. 1994. Post mortem diagnosis of Mycobacterium bovis infection in cattle. Vet. Microbiol. 40(1/2):53-63.<https://dx.doi.org/10.1016/03781135(94)90046-9><PMid:8073629>

Costa A.C.F., Silva N.S., Rocha V.C.M., Rosales Rodriguez C.A., Estrela-Lima A., Moreira E.L.T., Madruga C., Arruda S.M., Ferreira Neto J.S., Silva M.C.A. \& Oliveira E.M.D. 2012. Tipificação genética, através da técnica de Spoligotyping, de isolados de Mycobacterium bovis em animais abatidos na região metropolitana de salvador, Bahia, Brasil. Arqs Inst. Biológico, São Paulo, 77(2):233-237. <https://dx.doi.org/10.1590/1808-1657v77p2332010>

Costa P., Ferreira A.S., Amaro A., Albuquerque T., Botelho A., Couto I., Cunha M.V., Viveiros M. \& Inácio J. 2013. Enhanced detection of tuberculous mycobacteria in animal tissues using a semi-nested probe-based realtime PCR. Plos One 8(11):e81337. <https://dx.doi.org/10.1371/journal. pone.0081337><PMid:24278425>

Damina M.S., Owoludun O.A., Chukwukere S., Ameh J.A. \& Aliyu M.M. 2011. The use of deletion analysis in the detection of Mycobacterium bovis, Mycobacterium tuberculosis and Mycobacterium africanum among slaughtered cattle in Plateau state, North Central Nigeria. Niger. Vet. J. 32(1):9-15. <https://dx.doi.org/10.4314/nvj.v32i1.69002>

Dias R.A., UIloa-Stanojlovic F.M., Belchior A.P.C., Ferreira R.S., Gonçalves R.C., Aguiar R.S.C.B., Sousa P.R., Santos A.M.A., Amaku M., Ferreira F., Telles E.O., Grisi-Filho J.H.H., Gonçalves V.S.P., Heinemann M.B. \& Ferreira Neto J.S. 2016 Prevalence and risk factors for bovine tuberculosis in the state of São Paulo, Brazil. Semina, Ciênc. Agrárias 37(5):3673-3684. <https:// dx.doi.org/10.5433/1679-0359.2016v37n5Supl2p3673>

Fráguas S.A., Cunha-Abreu M.S., Ferreira A.M.R., Marassi C.D., Oelemann W., Fonseca L.S., Ferreira R. \& Lilenbaum W. 2008. Estudo comparativo de métodos complementares para o diagnóstico da tuberculose bovina em animais reagentes à tuberculinização. Revta Bras. Ciênc. Vet. 15(3):117121. <https://dx.doi.org/10.4322/rbcv.2014.211>

Furlanetto L.V., Figueiredo E.E.S., Conte Junior C.A., Carvalho R.C.T., Silva F.G.S., Silva J.T., Lilinbaum W. \& Paschoalin V.M.F. 2012. Uso de métodos complementares na inspeção post mortem de carcaças com suspeita de tuberculose bovina. Pesq. Vet. Bras. 32(11):1138-1144. <https://dx.doi. org/10.1590/S0100-736X2012001100011>

GhavideL M., Mansury D., Nourian K. \& Ghazvini K. 2018. The most common spoligotype of Mycobacterium bovis isolated in the world and the recommended loci for VNTR typing; a systematic review. Microb. Pathog. 118:310-315. <https://dx.doi.org/10.1016/j.micpath.2018.03.036><PMid:29578066>

Gibson A.L., Hewinson G., Goodchild T., Watt B., Story A., Inwald J. \& Drobniewki F.A. 2004. Molecular epidemiology of disease due to Mycobacterium bovis in humans in the United Kingdom. J. Clin. Microbiol., 42(1):431-434. <https://dx.doi.org/10.1128/jcm.42.1.431-434.2004><Pmid:14715798>

Grisi Filho J.H.H., Rosales C.A.R., Ferreira F., Amaku M., Dias R.A. \& Ferreira Neto J.S. 2011. Análise epidemiológica das condenações de bovinos por tuberculose em abatedouros do estado de São Paulo. Arqs Inst. Biológico, São Paulo, 78(2):175-181.<https://dx.doi.org/10.1590/1808-1657v78p1752011>

Haddad N., Masselot M. \& Durand B. 2004. Molecular differentiation of Mycobacterium bovis isolates. Review of main techniques and applications. Res. Vet. Sci. 76(1):1-18. <https://dx.doi.org/10.1016/s0034-5288(03)00078-x> $<$ PMid:14659724>

Haddad N., Ostyn A., Karoui C., Masselot M., Thorel M.F., Hughes S.L., Inwald J., Hewinson R.G. \& Durand B. 2001. Spoligotype diversity of Mycobacterium bovis strains isolated in France from 1979 to 2000. J. Clin. Microbiol. 39(10):3623-3632. <https://dx.doi.org/10.1128/JCM.39.10.36233632.2001><PMid:11574583>

IBGE 2017. Produção da Pecuária Municipal. Instituto Brasileiro de Geografia e Estatística, Rio de Janeiro, 8p. Available at <https://biblioteca.ibge.gov. $\mathrm{br} /$ visualizacao/periodicos/84/ppm_2017_v45 br_ informativo.pdf> Accessed on Feb. 3, 2019.

IPECE 2018. Instituto de Pesquisa e Estratégia Econômica do Ceará (IPECE). Ipece Informe 128:10-12.

Kamerbeek J., Schouls L., Kolk A., Van Agterveld M., Van Soolingen D., Kuijper S., Bunschoten A., Molhuizen H., Shaw R., Goyal M. \& Van Embde J. 1997. Simultaneous detection and strain differentiation of Mycobacterium tuberculosis for diagnosis and epidemiology. J. Clin. Microbiol. 35(4):907-914. <https://dx.doi.org/10.1128/JCM.35.4.907-914.1997><PMid:9157152>

Kremer K., Van Soolingen D., Frothingham R., Haas W.H., Hermans P.W.M., Martín C., Palittapongarnpim P., Plikaytis B.B., Riley L.W., Yakrus M.A., Musser J.M. \& Van Embden J.D.A. 1999. Comparison of methods based on different molecular epidemiological markers for typing of Mycobacterium tuberculosis complex strains: interlaboratory study of discriminatory power and reproductility. J. Clin. Microbiol. 37(8):2607-2618. <https://dx.doi. org/ 10.1128/JCM.37.8.2607-2618.1999><PMid:10405410>

Machado L.N.C, Marcondes N.R., Leite C.Q.F., Santos A.C.B., Pavan F.R., Baldin V.P., Castilho A.L., Siqueira V.L., Baeza L.C., Berghs H. \& Cardoso R.F. 2014. First baseline of circulating genotypic lineages of Mycobacterium tuberculosis 
in patients from the Brazilian borders with Argentina and Paraguay. Plos One 9(9):1-9. <https://dx.doi.org/10.1371/journal.pone.0107106>

Matos F., Cunha M.V., Canto A., Albuquerque T., Amado A. \& Botelho A. 2010. Snapshot of Mycobacterium bovis and Mycobacterium caprae infections in livestock in an area with a low incidence of bovine tuberculosis. J. Clin. Microbiol. 48(11):4337-4339. <https://dx.doi.org/10.1128/JCM.01762-10> <PMid:20844227>

Mendes R.E., Schneider A.F., Werlich D.E., Lucca N.J., Lorenzett M.P. \& Pilati C. 2013. Estudo anatomopatológico em tecidos condenados pelo serviço de inspeção federal (SIF) por suspeita de tuberculose. Ciênc. Anim. Bras. 14(4):448-453. <https://dx.doi.org/10.5216/cab.v14I4.8581>

Nascimento E.T.S. 2014. Aspectos epidemiológicos da tuberculose bovina em Quixeramobim (CE): bacia leiteira do Sertão Central do Ceará. Master's Thesis, Universidade Estadual do Ceará. Fortaleza. 71p.

Nassar A.F., Miyashiro S., Oliveira C.G., Pacheco W.A. \& Ogata R.A. 2007. Isolation and identification of bovine tuberculosis in a Brazilian herd (São Paulo). Mem. Inst. Oswaldo Cruz 102(5):639-642. <https://dx.doi. org/10.1590/S0074-02762007005000073>

Okeke L.A., Cadmus S., Okeke I.O., Muhammad M., Awoloh O., Dario D., Waziri E.N., Olayinka A., Nguku P.M. \& Fawole 0. 2014. Prevalence and risk factors of Mycobacterium tuberculosis complex infection in slaughtered cattle at Jos South Abattoir, Plateau State, Nigeria. Pan Afr. Med. J. 18(supl.1):7. <https:// dx.doi.org/10.11694/pamj.supp.2014.18.1.3841><PMid:25328626>

Oliveira L.E.D., Nonato I.A., Nascimento G.A.M., Nascimento A.A.T., Serrano M.T.L. \& Carvalho G.D. 2012. Tuberculose bovina protraída: relato de caso. J. Bras. Ciênc. Anim. 5(10):397-405.

Pacheco A.M., Hamzè A.L., Avanza M.F.B., Pereira D.M., Pereira R.E.P., Cipriano R.S. \& Lot R.F.S. 2009. Tuberculose bovina - relato de caso. Revta Cient. Eletrôn. Med. Vet. VII(13):1-5. <http://faef.revista.inf.br/site/a/927tuberculose-bovina-relato-de-caso.html>

Paes A.C. \& Franco M.M.J. 2016. Tuberculose em animais de produção, p.512542. In: Megid J., Ribeiro M.G. \& Paes A.C. (Eds), Doenças Infecciosas em Animais de Produção e de Companhia. Roca, Rio de Janeiro.

Parreiras P.M., Andrade G.I., Nascimento T.F., Oelemann M.C., Gomes H.M., Alencar A.P., Assis R.A., Mota P.M.P.C., Pereira M.A.S., Lobato F.C.F., Lage A.P. \& Suffys P.N. 2012. Spoligotyping and variable number tandem repeat analysis of Mycobacterium bovis isolates from cattle in Brazil. Mem. Inst. Oswaldo Cruz 107(1):64-73. <https://dx.doi.org/10.1590/S007402762012000100009>

Pérez-Lago L., Navarro Y. \& García-de-Viedma D. 2014. Current knowledge and pending challenges in zoonosis caused by Mycobacterium bovis: a review. Res. Vet. Sci. 97(supl.):S94-S100. <https://dx.doi.org/10.1016/j. rvsc.2013.11.008><PMid:24360647>

Perrez A.M., Ward M.P., Torres P. \& Ritacco V. 2002 Use of spatial statistics and monitoring data to identify clustering of bovine tuberculosis in Argentina. Prev. Vet. Med. 56(1):63-74. <https://dx.doi.org/10.1016/ s0167-5877(02)00124-1><PMid:12419600>

Pinto P.S.A., Faria J.E., Viloria M.I.V. \& Bevilacqua P.D. 2002. Exame microbiológico da tuberculose como subsídio à inspeção post-mortem de bovinos. Revta Bras. Saúde Prod. Anim. 3(1):10-15.

Ramos D.F., Silva P.E.A. \& Dellagostin O.A. 2015. Diagnosis of bovine tuberculosis: review of main techniques. Braz. J. Biol. 75(4):830-837. <https://dx.doi. org/10.1590/1519-6984.23613>

Ramos F., Silva A.B.S., Fagundes M.Q., Von Groll A., Silva P.E. \& Dellagostin O.A. 2014. Molecular typing of Mycobacterium bovis isolated in the south of Brazil. Braz. J. Microbiol. 45(2):657-660.<https://dx.doi.org/10.1590/ S1517-83822014000200039>
Ramos J.M., Heinemann M.B., Ferreira Neto J.S., Souza Filho A.F., Cárdenas N.C., Dantas A.F.M., Alves C.J. \& Azevedo S.S. 2018. Isolation and identification of Mycobacterium bovis in bovines with positive reaction to the tuberculin test in the state of Paraíba, northeast Brazil. Arqs Inst. Biológico, São Paulo, 85:e0842016. <https://dx.doi.org/10.1590/1808-1657000842016>

Richards W.D. \& Wright H.S. 1983. Preservation of tissue specimens during transport to mycobacteriology laboratories. J. Clin. Microbiol. 17(3):393-395. <https://dx.doi.org/10.1128/JCM.17.3.393-395.1983><PMid:6341397>

Rocha V.C.F. 2013. Avaliação do Spoligotyping, MIRU-VNTR e Multispacer Sequence Typing na discriminação de isolados autóctones de Mycobacterium bovis. Doctoral Dissertation, Universidade de São Paulo, São Paulo. 75p.

Rocha V.C.F., Figueiredo S.C., Rosales C.A.R, Grisi Filho J.H.H., Keid L.B., Soares R.M. \& Ferreira Neto J.S. 2013. Molecular discrimination of Mycobacterium bovis in São Paulo, Brazil. Vector Borne Zoonotic Dis. 13(1):17-21. <https:// dx.doi.org/10.1089/vbz.2012.1035> <PMid:23199273>

Rodriguez C.A.R. 2005. Sistema de detecção de focos de tuberculose bovina no estado de São Paulo utilizando métodos moleculares e epidemiológicos. Doctoral Dissertation, Universidade de São Paulo. São Paulo. 86p.

Rodriguez C.A.R., Zumarraga M.J., Oliveira E.M.D., Cataldi A.A., Romano M.I., Otto H.H., Bonafé V.L. \& Ferreira Neto J.S. 2004. Caracterização molecular de isolados de Mycobacterium bovis do estado de São Paulo Brasil, utilizando a técnica de Spoligotyping. Arqs Inst Biológico, São Paulo, 71(3):277-282.

Roxo E. 1997. Mycobacterium bovis como causa de zoonose. Revta Ciênc. Farm. 18(1):101-108.

Shi J., Zheng D., Zhu Y., Ma X., Wang S., Li H., \& Xing J. 2018. Role of MIRU-VNTR and spoligotyping in assessing the genetic diversity of Mycobacterium tuberculosis in Henan Province, China. BMC Infect. Dis. 18(447):1-12. <https://dx.doi.org/10.1186/s12879-018-3351-y>

Silva D.A.V., Bürger K.P., Martins A.M.C.V. \& Providello A. 2014. Identificação de lesões macroscópicas sugestivas de tuberculose bovina. Revta Bras. Hig. Sanid. Anim. 8(2):149-160. <https://dx.doi.org/10.5935/19812965.20140026>

Silva S.C.G., Alves A.D.F., Almeida T.J.O., Sá P.C.L., Souza Filho A.F., Cárdenas N.C., Ferreira Neto J.S., Heinemann M.B., Azevedo S.S. \& Torres M.B.A.M. 2018. Isolation and identification of Mycobacterium bovis in cattle slaughtered from an abattoir in Garanhuns, Pernambuco. Semina, Ciênc. Agrárias 39(1):157-166. <https://dx.doi.org/10.5433/1679-0359.2018v39n1p157>

Skuce R.A., Allen A. R. \& McDowell S.W.J. 2012. Herd-level risk factors for bovine tuberculosis: a literature review. Vet. Med. Int. 2012: 621210. <https://dx.doi.org/10.1155/2012/621210> <PMid:2296647>

Van Embden J.D., Van Gorkom T., Kremer K., Jansen R., Van Der Zeijst B.A. \& Schouls L.M. 2000. Genetic variation and evolutionary origin of the direct repeat locus of Mycobacterium tuberculosis complex bacteria. J. Bacterial 182(9):2393-2401.<https://dx.doi.org/10.1128/jb.182.9.2393-2401.2000> <PMid:10762237>

Zanini M.S., Moreira E.C., Lopes M.T.P., Oliveira R.S., Leão S.C., Fioravanti R.L., Roxo E., tabela M., Romano M.I., Cataldi A. \& Salas C.E. 2001. Mycobacterium bovis: polymerase chain reaction identification in bovine lymphonode biopsies and genotyping in isolates from southeast Brazil by spolygotyping and restricion fragment length polymorphism. Mem. Inst. Oswaldo Cruz 96(6):1-5. <https://dx.doi.org/10.1590/S0074-02762001000600012>

Zumárraga M.J., Arriaga C., Barandiaran S., Cobos-Marín L., Waard J., EstradaGarcia I., Figueiredo T., Figueroa A., Giménez F., Gomes H.M., Gonzalez-yMerchand J.A., Macías A., Milián-Suazo F., Rodríguez C.A.R., Santillán M.A., Suffys P.N., Trangoni M.D., Zárraga A.M. \& Cataldi A. 2013. Understanding the relationship between Mycobacterium bovis spoligotypes from cattle in Latin American Countries. Res. Vet. Sci. 94(1):9-21. <https://dx.doi. org/10.1016/j.rvsc.2012.07.012><PMid:22884173> 